\title{
Synthesis and Characterization of Carbon Conditioned with Iron Nanoparticles Using Pineapple-Peel
}

\author{
G. García-Rosales ${ }^{1 *}$, L. C. Longoria-Gándara ${ }^{2}$, S. Martínez-Gallegos ${ }^{1}$, J. González-Juárez ${ }^{1}$ \\ ${ }^{1}$ Posgrade Department, Instituto Tecnologico de Toluca, Metepec, México \\ ${ }^{2}$ Scientific Reseach and Reactor, Instituto Nacional de Investigaciones Nucleares, \\ Ocoyoacac, México \\ Email: *gegaromx@yahoo.com.mx
}

Received September 3, 2013; revised October 30, 2013; accepted November 9, 2013

Copyright (C) 2013 G. García-Rosales et al. This is an open access article distributed under the Creative Commons Attribution License, which permits unrestricted use, distribution, and reproduction in any medium, provided the original work is properly cited.

\begin{abstract}
This paper presents the preparation of carbon conditioned with iron nanoparticles $(\mathrm{CI})$ using a pineapple peel treated with iron salts, carboxymethylcellulose sodium and hexamine. First, the pineapple peel was analyzed by thermo gravimetric analysis (TGA) to determine the optimal temperature for pyrolysis. The formation of carbon conditioned by iron nanoparticles was studied as a function of time at $30 \mathrm{~min}, 60 \mathrm{~min}, 90 \mathrm{~min}, 120 \mathrm{~min}, 150 \mathrm{~min}$ and $180 \mathrm{~min}$. Scanning electron microscopy (SEM) was used to identify changes in the morphology of the materials. The specific area of each material was obtained by the BET method. The elemental composition of pineapple-peel (PP), washed pineapple-peel (WPP) and carbon iron (CI), was determined by neutron activation analysis (NAA). The results show that the optimal time for obtaining spherical iron nanoparticles with a diameter between $10 \mathrm{~nm}$ and $30 \mathrm{~nm}$ is $180 \mathrm{~min}$ on the carbonaceous material with a specific surface area of $167 \mathrm{~m}^{2} / \mathrm{g}$.
\end{abstract}

Keywords: Pineapple; Carbon; Iron-Nanoparticles; Synthesis; Neutron Activation Analysis

\section{Introduction}

Iron nanoparticles are used in environmental applications, such as the removal of toxic metals from polluted water [1-3]; however, a major drawback is that their size limits direct application because handling is difficult unless they are recovered through an ultrafiltration system [4]. Therefore, a material that can function as a support is recommended for using iron nanoparticles [5-8]. Carbonaceous materials that are obtained from organic cellulosic waste and then conditioned with iron nanoparticles can be a good choice for environmental applications, such as the removal of metals in water [9-13]. The advantage of using carbon obtained from biomass and conditioned with iron nanoparticles is that synthesis of both the carbonaceous material and the nanoparticles can be performed simultaneously during pyrolysis, if the biomass has been previously chemically conditioned. In this work, pineapple peel conditioned with iron salts, hexamine and sodium carboxymethylcellulose was used to obtain carbonaceous material containing iron nanoparticles via pyrolysis. First, the pineapple peel was analyzed

*Corresponding author. by thermo gravimetric analysis (TGA) to determine the optimal pyrolysis temperature. Pyrolysis is performed at different reaction times: $30 \mathrm{~min}, 60 \mathrm{~min}, 90 \mathrm{~min}, 120 \mathrm{~min}$, $150 \mathrm{~min}$ and $180 \mathrm{~min}$. To determine the effect of pyrolysis time on both the morphology and the size of nanoparticles in the carbon matrix, characterization via scanning electron microscopy (SEM) and calculation of the specific surface area via the BET method were performed. Finally, the neutron activation analysis (NAA) was used to determine the elemental composition.

\section{Materials and Methods}

\subsection{Washing and Drying of Pineapple Peel}

For this study, pineapples obtained from Mexico were used. In the laboratory experiments, the peel was separated from the pineapple, then ground and sieved to obtain a size of $0.85 \mathrm{~mm}$. The material was washed several times with double-distilled water to remove surface impurities and then dried at $25^{\circ} \mathrm{C}$ for $24 \mathrm{~h}$. The pineapple peels were then repeatedly washed with water at $120^{\circ} \mathrm{C}$ for $15 \mathrm{~min}$ to remove the brown discoloration completely, and finally dried at $25^{\circ} \mathrm{C}$ for $24 \mathrm{~h}$. 


\subsection{Thermogravimetric Analysis}

To determine the optimal temperature for pyrolysis, a small amount of sample was placed directly onto a platinum crucible, and TGA was performed using a calorimetric SDT Q600 (TA Instruments-Waters) under $\mathrm{N}_{2}$ at a heating rate of $10^{\circ} \mathrm{C} \mathrm{min}{ }^{-1}$ with a temperature range of $25^{\circ} \mathrm{C}-800^{\circ} \mathrm{C}$.

\subsection{Synthesis}

A mixture of $12 \mathrm{~mL} \mathrm{C}_{28} \mathrm{H}_{30} \mathrm{Na}_{8} \mathrm{O}_{27}(2 \% \mathrm{w} / \mathrm{w}$; SigmaAldrich $\left.^{\circledR}\right), 18 \mathrm{~mL} \mathrm{Fe}\left(\mathrm{NO}_{3}\right)_{3} \cdot 9 \mathrm{H}_{2} \mathrm{O}(0.06 \mathrm{M}$; Sigma-Al$\left.\operatorname{drich}^{\circledR}, 98 \%\right)$ and $6 \mathrm{~mL}\left(\mathrm{CH}_{2}\right)_{6} \mathrm{~N}_{4}(0.5 \mathrm{M}$; Sigma-Aldrich $^{\circledR}, 99.9 \%$ ) was combined in a reactor under Ar with constant agitation. Once the mixture was homogenized, 3 g pineapple peel (mesh 20) was added to the mixture and agitated in an ultrasonic bath for 45 min prior to being placed in a fused alumina crucible, which was then subsequently introduced into a quartz tube under argon within a furnace (Lindberg ${ }^{\circledR} /$ Blue Model CC58114A-1). To determine the effect of synthesis time on the morphology of the nanoparticles, six samples were prepared using pyrolysis times of $30 \mathrm{~min}, 60 \mathrm{~min}, 90 \mathrm{~min}, 120 \mathrm{~min}$, $150 \mathrm{~min}$ and $180 \mathrm{~min}$; the products obtained were labeled CFe30, CFe60, CFe90, CFe120, CFe150 and CFe180, respectively.

\subsection{Scanning Electron Microscopy and Specific Surface Areas}

The morphology of the material was analyzed with a scanning electron microscope (Model JEOL ${ }^{\circledR}$ JSM-6610 $\mathrm{LV})$ at $25 \mathrm{kV}$. The samples were mounted on an aluminum holder with aluminum conductive tape and were then covered with a layer of gold approximately $150 \AA$ thick using a sputter coater (Desk II model, Denton Vacuum). In all cases, micrographs were obtained using a backscattered electron detector. The elemental compositions of the samples were then determined by energy dispersive spectroscopy (EDS) using an OXFORD spectrometer. The diameters of the particles obtained were measured using MeasureIt software (Olympus Soft Imaging Solutions). The specific surface area, pore volume and pore diameter of the carbonaceous materials were determined by the Brunauer-Emmett-Teller (BET) nitrogen adsorption method in a BELPREP-flow II surface area analyzer (BEL JAPAN Inc.). The dried and degassed samples were then analyzed by a multipoint $\mathrm{N}_{2}$ adsorption-desorption method at room temperature.

\subsection{Elemental Composition}

The NAA was performed using the comparator method. Approximately $30 \mathrm{mg}$ of each sample, PP (prewashed pineapple), PPL (pineapple washed) and CFe180 (carbon with iron), was encapsulated in polyethylene containers for the shorter irradiation times ( $30 \mathrm{~s}$ and $5 \mathrm{~min}$ ) and in quartz vials for irradiation of $20 \mathrm{~h}$. Lichen BCR-482 and IAEA-Soil 7 were used as reference materials. The encapsulated samples were irradiated for $30 \mathrm{~s}$ to 5 min with a thermal neutron flux $\cdot \mathrm{s}$ of $1.3 \times 10^{13} \mathrm{n} / \mathrm{cm}^{2}$ in an Irradiation System tire (SINCA) in a TRIGA Mark III reactor (ININ, Mexico) and for irradiation of $20 \mathrm{~h}$ in the Fixed Irradiation System (SIFCA) with a flow of $9 \times 10^{12}$ $\mathrm{n} / \mathrm{cm}^{2} \cdot \mathrm{s}$. The activity of the samples was measured in a gamma spectrometer equipped with an ORTEC ${ }^{\circledR}$ hyperpure $\mathrm{Ge}$ detector.

\section{Results and Discussion}

\subsection{Thermogravimetric Analysis}

Figure 1 shows the relative mass loss (TGA) and differential thermal analysis (DTA) curves corresponding to the dried pineapple-peel.

The endothermic mass loss $(8.3 \mathrm{wt} \%)$ observed for temperatures lower than $120^{\circ} \mathrm{C}$ can be attributed to water desorption $[14,15]$. The second mass loss $(30.56 \mathrm{wt} \%)$ between $120^{\circ} \mathrm{C}$ and $190^{\circ} \mathrm{C}$ is associated with the decomposition of organic substances. Beyond this temperature, thermal degradation of the main components of the biomass begins: from $190^{\circ} \mathrm{C}-320^{\circ} \mathrm{C}$, hemicellulose degrades, followed by cellulose from $320^{\circ} \mathrm{C}-400^{\circ} \mathrm{C}$, and then lignin above $400^{\circ} \mathrm{C}(59.94 \mathrm{wt} \%)$ [16]. In agreement with Gutierrez et al. [17], a pineapple-peel has an average fiber content of $67.88 \%$ (including cellulose, hemicellulose, lignin and silica), which renders this waste biomass suitable for obtaining carbonaceous material [18]. Stabilization of the material was observed above $625^{\circ} \mathrm{C}$, and the total weight loss calculated until $650^{\circ} \mathrm{C}$ was 77.47 $\mathrm{wt} \%$. Based on this result, the selected pyrolysis temperature was $650^{\circ} \mathrm{C}$ to obtain carbonaceous material.

\subsection{Effect of the Pyrolysis Time on Nanoparticle Morphology and Specific Surface Area}

To characterize the textural properties of the carbona-

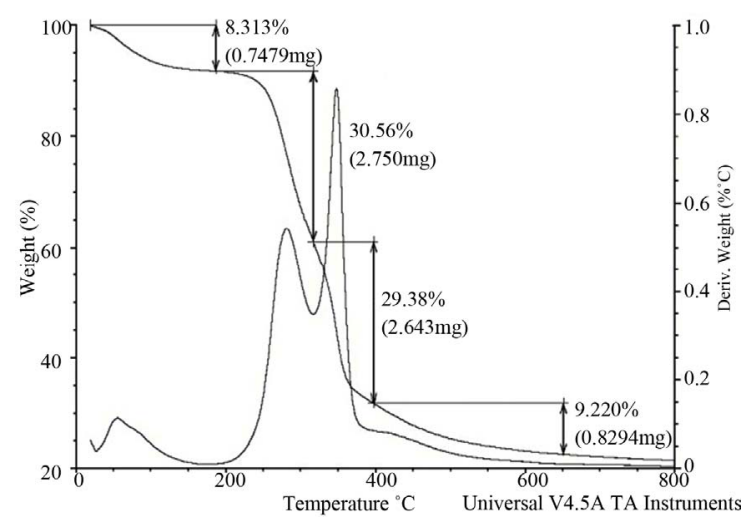

Figure 1. Thermogravimetric and DTA curves of pineapple peel powder. 
ceous materials obtained at $30 \mathrm{~min}, 60 \mathrm{~min}, 90 \mathrm{~min}, 120$ $\mathrm{min}, 150 \mathrm{~min}$ and $180 \mathrm{~min}$, these materials were chemi- cally and morphologically analyzed. Figure 2(a) shows that the material synthesized at 30 minutes does not possess
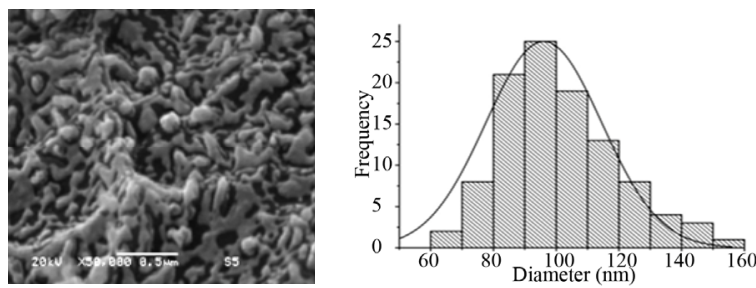

(a)
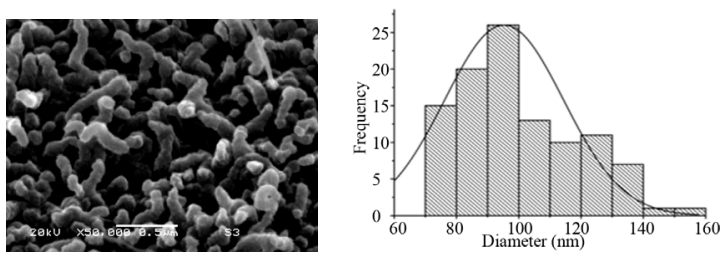

(b)
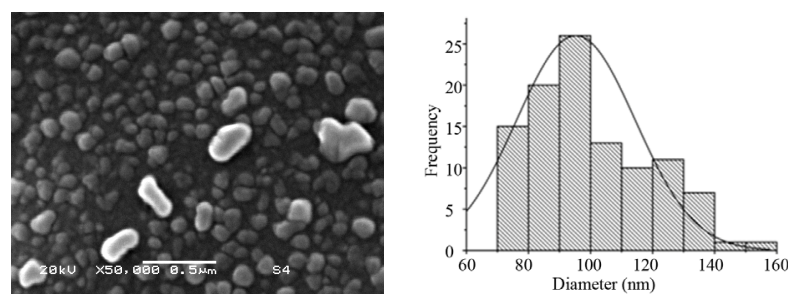

(c)
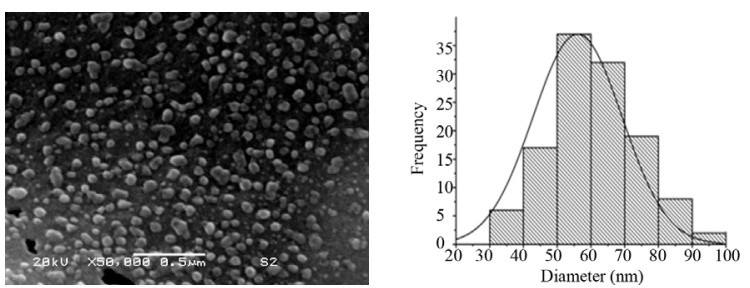

(d)
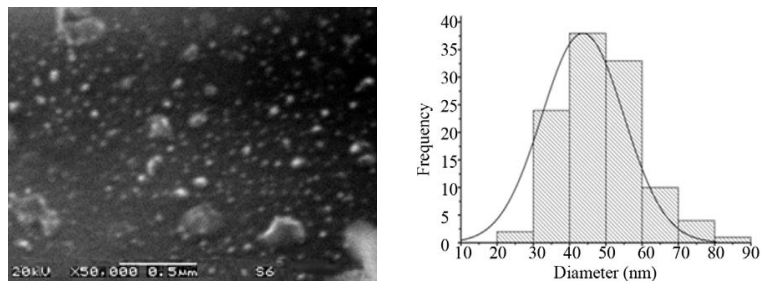

(e)
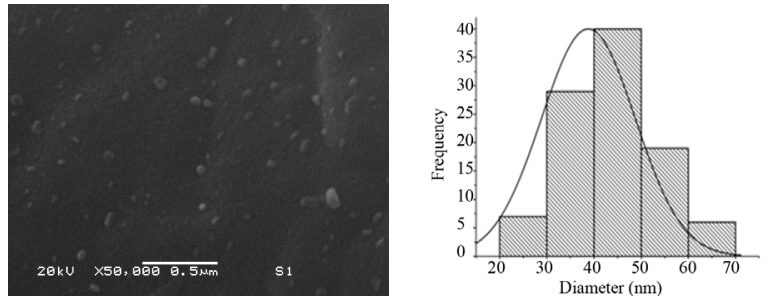

(f)
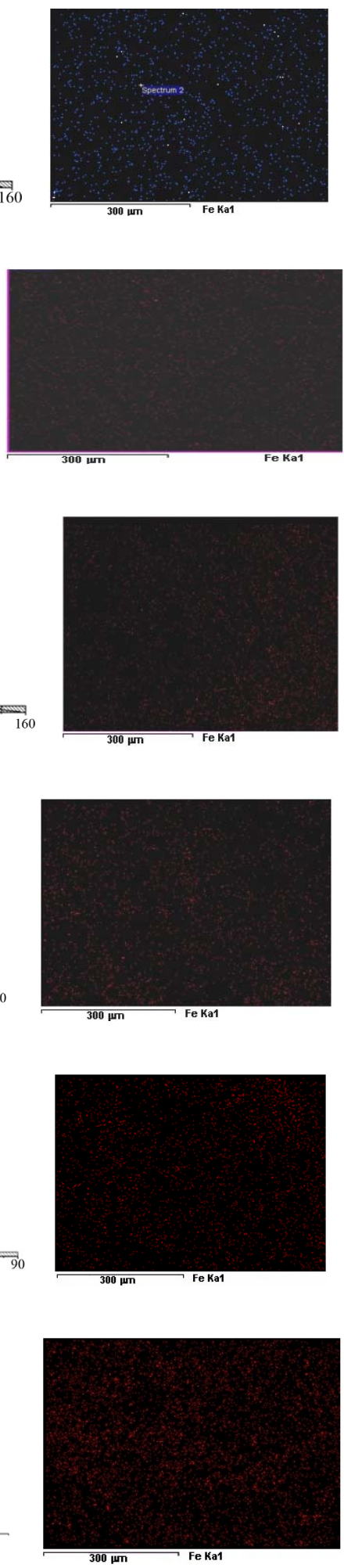

$300 \mu$

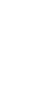


a homogeneous morphology; there are rough spots. Nucleation of spherical particles with an average diameter of $114.8 \mathrm{~nm}(\sigma=19.3)$ occurs, which is in agreement with EDS analysis, having a composition of $\mathrm{C}(82 \mathrm{wt} \%)$, $\mathrm{O}(14.22$ wt $\%), \mathrm{Na}(1.43$ wt $\%), \mathrm{Si}(0.64$ wt $\%), \mathrm{K}(0.29$ $\mathrm{wt} \%), \mathrm{Ca}(0.76 \mathrm{wt} \%)$ and $\mathrm{Fe}(0.64 \mathrm{wt} \%)$.

In Figure 2(b), for the pyrolysis sample obtained at 60 min, there are chains of spheres with an average diameter of $88.06 \mathrm{~nm}(\sigma=12.22)$ forming filaments with a length of $300 \mathrm{~nm}-600 \mathrm{~nm}$. The composition of the spheres is $\mathrm{C}$ (77.63 wt $\%)$, O (17.50 wt \%), Na (2.01 wt\%), Al (0.45 wt $\%)$, Si ( $1.18 w t \%), \mathrm{Ca}\left(0.28 \mathrm{wt}^{0} \%\right)$ and $\mathrm{Fe}(0.95 \mathrm{wt} \%)$. The sample obtained at 90 minutes (Figure 2(c)) forms a defined group of particles apparently caused by segregation of the filaments previously observed at $30 \mathrm{~min}$ (Figure 1(b)). The morphology of some of these particles is not completely spherical; there are ovals $250 \times 125 \mathrm{~nm}$ in dimension and spherical particles with an average diameter of $71.21 \mathrm{~nm}(\sigma=11.93)$. Elemental analysis shows a presence composition of $\mathrm{C}(80.92 \mathrm{wt} \%), \mathrm{O}$ (16.03 wt $\%)$, Na (1.83 wt\%), Si $(0.31 \mathrm{wt} \%)$, Ca $(0.63$ $\mathrm{wt} \%)$ and $\mathrm{Fe}(0.38 \mathrm{wt} \%)$. Figure 2(d) shows the sample obtained at $120 \mathrm{~min}$ in which spherical nanoparticles are dispersed with an average diameter of $57.69 \mathrm{~nm}(\sigma=$ 9.02) and have an elemental composition of $\mathrm{C}(82.45$ wt $\%)$, O (11.60 wt \%), Na (1.36 wt \%), Mg (0.34 wt\%), Si $(1.10 \mathrm{wt} \%), \mathrm{K}(0.05 \mathrm{wt} \%), \mathrm{Ca}(0.76 \mathrm{wt} \%)$, and $\mathrm{Fe}(1.34$ $\mathrm{wt} \%$ ). In the sample obtained at 150 minutes (Figure 2(e)), the nanoparticles are the best dispersed and have an average diameter of $44.09 \mathrm{~nm}(\sigma=17.09)$; their composition consists of $\mathrm{C}(75.02 \mathrm{wt} \%), \mathrm{O}(18.48 \mathrm{wt} \%), \mathrm{Na}$ (2.26 wt \%), Si (1.08 wt\%), K (0.36 wt\%), Ca (0.77 wt\%) and $\mathrm{Fe}(1.03 \mathrm{wt} \%)$. At $180 \mathrm{~min}$ (Figure 2(f)), there is a reduction in particle size without noticeable changes in the spherical shape, having an average diameter of 32.94 $\mathrm{nm}(\sigma=6.75)$; the composition is $\mathrm{C}(75.57 \mathrm{wt} \%)$, O (18.47 wt $\%)$, Na (1.81 wt\%), Si $(0.95 \mathrm{wt} \%), \mathrm{K}(0.38$ wt $\%), \mathrm{Ca}(1.58 \mathrm{wt} \%)$ and Fe $(1.24 \mathrm{wt} \%)$. The sample obtained after 180 minutes of pyrolysis has a more defined particle size as well as spherical morphology.

This effect can be attributed to the use of carboxymethyl cellulose sodium and hexamine, which favors the formation of iron nanoparticles of uniform size at this time scale $[19,20]$.

To determine the specific area and pore size of the materials, a carbon sample without iron (CB180) was synthesized to determine the influence of the presence of iron nanoparticles on the specific area. The results of this experiment on the effect of iron nanoparticles are summarized in Table 1. In general, the specific area in all materia ls is more strongly affected by the pyrolysis time, with larger values observed for the samples containing iron compared to the $\mathrm{CB}$ sample.

The specific area of CFe180 is higher than that of $\mathrm{CFe} 30$ by $91.3 \mathrm{~m}^{2} / \mathrm{g}$, thereby implying that the specific areas increase with increased pyrolysis time due to the formation of iron nanoparticles in the carbonaceous material.

However, a difference of $23.1 \mathrm{~m}^{2} / \mathrm{g}$ between the specific areas of $\mathrm{CFe} 180$ and $\mathrm{CB}$ is attributed to the presence of iron nanoparticles [21]. CFe60 and $\mathrm{CFe} 120$ possess larger specific areas than $\mathrm{CFe} 180$, which can be attributed to the presence of iron nanoparticles with different morphologies and to changes in the porosity of the carbonaceous matrix that are associated with the pyrolysis process [22]. However, the value of CFe180 is greater, which could favor its use in environmental applications for the removal of contaminants from water.

\subsection{Chemical Composition}

Table 2 lists the results from neutron activation analysis of the PP, PPL, CB and CFe180 samples. Initially, PPL contains these elements: $\mathrm{Al}, \mathrm{Br}, \mathrm{Ce}, \mathrm{Co}, \mathrm{Cr}, \mathrm{Cs}, \mathrm{Eu}, \mathrm{Fe}$, $\mathrm{Hf}, \mathrm{K}, \mathrm{La}, \mathrm{Mg}, \mathrm{Mn}, \mathrm{Na}, \mathrm{Rb}, \mathrm{Sb}, \mathrm{Sc}$ and $\mathrm{Zn}$. The majority of these elements are present in the soil where a plant grows and can accumulate in and be incorporated into their structure during nutrient absorption, which is necessary for plant growth [23].

Table 1. Specific area, volume and diameter of pore in carbonaceous materials.

\begin{tabular}{cccc}
\hline Material & Specific area $\left(\mathrm{m}^{2} / \mathrm{g}\right)$ & Volume of pore $\left(\mathrm{cm}^{3} / \mathrm{g}\right)$ & Diameter of pore $(\mathrm{nm})$ \\
\hline $\mathrm{CB}$ & 98.80 & 0.0598 & 2.42 \\
$\mathrm{CFe} 30$ & 75.70 & 0.0496 & 2.62 \\
$\mathrm{CFe} 60$ & 284.41 & 0.1668 & 2.34 \\
$\mathrm{CFe} 90$ & 162.36 & 0.0917 & 2.26 \\
$\mathrm{CFe} 120$ & 182.50 & 0.0931 & 2.04 \\
$\mathrm{CFe} 150$ & 161.03 & 0.0963 & 2.39 \\
$\mathrm{CFe} 180$ & 167.00 & 0.1053 & 2.52 \\
\hline
\end{tabular}


Table 2. Elemental compositions of PP, PPL, CB y CFe.

\begin{tabular}{|c|c|c|c|c|}
\hline Isotop & PP [ppm] & PPL [ppm] & CB [ppm] & CFe [ppm] \\
\hline${ }^{28} \mathrm{Al}$ & $144 \pm 14$ & $60 \pm 6$ & $\mathrm{D}$ & $498 \pm 14$ \\
\hline${ }^{82} \mathrm{Br}$ & $17 \pm 0.87$ & $1.46 \pm 0.07$ & $4 \pm 0.25$ & $4.6 \pm 0.24$ \\
\hline${ }^{141} \mathrm{Ce}$ & $0.122 \pm 0.02$ & ** & $0.3 \pm 0.0293$ & $0.14 \pm 0.02$ \\
\hline${ }^{60} \mathrm{Co}$ & $0.29 \pm 0.01$ & $0.1612 \pm 0.007$ & $0.24 \pm 0.0116$ & $0.29 \pm 0.014$ \\
\hline${ }^{51} \mathrm{Cr}$ & $2.21 \pm 0.07$ & $0.9382 \pm 0.0395$ & $2.95 \pm 0.091$ & $2.6 \pm 0.08$ \\
\hline${ }^{134} \mathrm{Cs}$ & $0.074 \pm 0.0001$ & ** & $0.065 \pm 0.0073$ & $0.074 \pm 0.006$ \\
\hline${ }^{152} \mathrm{Eu}$ & $0.007 \pm 0.0001$ & $0.0032 \pm 0$ & $0.0083 \pm 0.0014$ & $0.0074 \pm 0.001$ \\
\hline${ }^{59} \mathrm{Fe}$ & $4020 \pm 8$ & $36.71 \pm 3$ & $4409 \pm 85$ & $5197 \pm 98$ \\
\hline${ }^{181} \mathrm{Hf}$ & $0.018 \pm 0.0001$ & $0.0098 \pm 0.002$ & $0.08 \pm 0.0056$ & $0.020 \pm 0.004$ \\
\hline${ }^{42} \mathrm{~K}$ & $28342 \pm 1063$ & $362 \pm 46$ & $* *$ & ** \\
\hline${ }^{140} \mathrm{La}$ & $0.159 \pm 0.01$ & ** & ** & ** \\
\hline${ }^{27} \mathrm{Mg}$ & $460 \pm 6$ & $193 \pm 24$ & $456 \pm 105$ & $662 \pm 79$ \\
\hline${ }^{56} \mathrm{Mn}$ & $92 \pm 3$ & $60 \pm 1.7$ & $124 \pm 4$ & $152 \pm 4$ \\
\hline${ }^{24} \mathrm{Na}$ & $* *$ & ** & $32947 \pm 929$ & $30499 \pm 851$ \\
\hline${ }^{86} \mathrm{Rb}$ & $2.24 \pm 0.3$ & $0.90 \pm 0.1759$ & $2 \pm 0.4$ & $3 \pm 0.4$ \\
\hline${ }^{124} \mathrm{Sb}$ & $0.783 \pm 0.03$ & $0.03 \pm 0.0045$ & $0.58 \pm 0.0263$ & $0.8424 \pm 0.04$ \\
\hline${ }^{46} \mathrm{Sc}$ & $0.010 \pm 0.0001$ & $0.005 \pm 0.0004$ & $0.014 \pm 0.0007$ & $0.0112 \pm 0.0008$ \\
\hline${ }^{65} \mathrm{Zn}$ & $132 \pm 6$ & $42 \pm 2$ & $115 \pm 5$ & $136 \pm 6$ \\
\hline
\end{tabular}

${ }^{* *}$ No detected.

In the PP, PPL, CB and CFe samples, the elements that are present at low concentrations $(0-0.08 \mathrm{ppm})$ are $\mathrm{Eu}, \mathrm{Sc}$ and Hf, where Hf is the most abundant; this result is in accordance with Gutiérrez et al., who considered these elements to be attached to the plant structure because they aregenerally present in the soil. Meanwhile, Cs, La, Co and $\mathrm{Ce}$ are present at concentrations between $0.050 \mathrm{ppm}$ and $0.30 \mathrm{ppm} ; \mathrm{Sb}, \mathrm{Cr}$ and $\mathrm{Rb}$ have concentrations of 1 ppm to $4 \mathrm{ppm}$. Br, Mn, $\mathrm{Zn}$ and $\mathrm{Al}$ are found at high concentrations because they are considered to be essential components of plant tissues, especially in the CFe sample in which the concentration of $\mathrm{Al}$ is nearly $500 \mathrm{ppm}$.

$\mathrm{Mn}$ and $\mathrm{Zn}$ are present because they are essential for plant metabolism. This analysis also confirmed the presence of $\mathrm{Mg}$ and $\mathrm{Fe}$ as natural components in the pineapple peel (Ananas comosus) because both elements are essential for photosynthesis.

$\mathrm{Na}$ and $\mathrm{K}$ are the most abundant elements; the presence of $\mathrm{Na}$ in the $\mathrm{CFe}$ and $\mathrm{CB}$ samples is mainly due to the use of sodium carboxymethyl cellulose during the chemical conditioning of the pineapple-peel. The increase in concentration of the elemental compositions in PPL, CB and CFE can be attributed to the loss of organic matter during pyrolysis [24]. The presence of different elements in these samples could facilitate the formation of active sites on the material surface, thereby favoring their effectiveness as a sorbent in the removal of metal contaminants in an aqueous phase [25].

\section{Conclusion}

In this paper, the use of a pineapple peel that was chemically conditioned with iron salts, sodium carboxymethyl cellulose and hexamine yielded a carbonaceous material with iron nanoparticles following pyrolysis. The synthesis time had a significant effect on the morphology, particle size and specific area of the carbonaceous material was obtained. The elemental composition determined by Neutronic Activation Analysis of CP, CPL, and CFe showed the presence of $\mathrm{Al}, \mathrm{Co}, \mathrm{Cr}, \mathrm{Cs}, \mathrm{Fe}, \mathrm{Hf}, \mathrm{K}, \mathrm{Mg}$, $\mathrm{Mn}, \mathrm{Na}, \mathrm{Rb}, \mathrm{Sc}, \mathrm{Zn}, \mathrm{Ce}, \mathrm{Eu}, \mathrm{La}, \mathrm{Sb}$ and Br. The method proposed in this study provides a simple technique for synthesizing iron nanoparticles in a carbon matrix.

\section{Acknowledgements}

The authors gratefully acknowledge DGEST for partial financial support of this work and thank Jorge Perez for his helpful assistance with electron microscopy analysis. 


\section{REFERENCES}

[1] M. Dickinson and T. B. Scott, "The Application of ZeroValent Iron Nanoparticles for the Remediation of a Uranium-Contaminated Waste Effluent," Journal of Hazardous Materials, Vol. 178, No. 1-3, 2010, pp. 171-179. http://dx.doi.org/10.1016/j.jhazmat.2010.01.060

[2] M. Diao and M. Yao, "Use of Zero-Valent Iron Nanoparticles in Inactivating Microbes," Water Research, Vol. 43, No. 20, 2009, pp. 5243-5251.

http://dx.doi.org/10.1016/j.watres.2009.08.051

[3] H.-L. Lien and W. Zhang, "Nanoscale Iron Particles for Complete Reduction of Chlorinated Ethenes," Colloids and Surfaces A: Physicochemical and Engineering Aspects, Vol. 191, No 1-2, 2001, pp. 97-105. http://dx.doi.org/10.1016/S0927-7757(01)00767-1

[4] V. Zaspalis, A. Pagana and S. Sklari, "Arsenic Removal from Contaminated Water by Iron Oxide Sorbents and Porous Ceramic Membranes," Desalination, Vol. 217, No. 1-3, 2007, pp. 167-180. http://dx.doi.org/10.1016/i.desal.2007.02.011

[5] X. Zhang, S. Lin, X.-Q. Lu and Z.-L. Chen, "Removal of $\mathrm{Pb}$ (II) from Water Using Synthesized Kaolin Supported Nanoscale Zero-Valent Iron," Chemical Engineering Journal, Vol. 163, No. 3, 2010, pp. 243-248. http://dx.doi.org/10.1016/j.cej.2010.07.056

[6] C.-B. Wang and W.-X. Zhang, "Synthesizing Nanoscale Iron Particles for Rapid and Complete Dechlorination of TCE and PCBs," Environmental Science and Technology, Vol. 31, No. 7, 1997, pp. 2154-2156. http://dx.doi.org/10.1021/es970039c

[7] H. Zhu, Y, Jia, X. Wu and H. Wang, "Removal of Arsenic from Water by Supported Nano Zero-Valent Iron on Activated Carbon," Journal of Hazardous Materials, Vol. 172, No. 2-3, 2009, pp. 1591-1596.

http://dx.doi.org/10.1016/j.jhazmat.2009.08.031

[8] W. Wang, M. Zhou, Q. Mao, J. Yue and X. Wang, "Novel NaY Zeolite-Supported Nanoscale Zero-Valent Iron as an Efficient Heterogeneous Fenton Catalyst," $\mathrm{Ca}$ talysis Communications, Vol. 11, No. 11, 2010, pp. 937941. http://dx.doi.org/10.1016/j.catcom.2010.04.004

[9] J. F. González, S. Román, J. M. Encinar and G. Martínez, "Pyrolysis of Various Biomass Residues and Char Utilization for the Production of Activated Carbons," Journal of Analytical and Applied Pyrolysis, Vol. 85, No. 1-2, 2009, pp. 134-141.

http://dx.doi.org/10.1016/j.jaap.2008.11.035

[10] J. Hayashi, T. Horikawa, I. Takeda, K. Muroyama and F. N. Ani, "Preparing Activated Carbon from Various Nutshells by Chemical Activation with $\mathrm{K}_{2} \mathrm{CO}_{3}$," Carbon, Vol. 40, No. 13, 2002, pp. 2381-2386. http://dx.doi.org/10.1016/S0008-6223(02)00118-5

[11] L. Lorenzen, J. S. J. Van Deventer and W. M. Landi, "Factors Affecting the Mechanism of the Adsorption of Arsenic Species on Activated Carbon," Minerals Engineering, Vol. 8, No. 4-5, 1995, pp. 557-569. http://dx.doi.org/10.1016/0892-6875(95)00017-K

[12] Z. Liu, F.-S. Zhanga and R. Sasai, "Arsenate Removal from Water Using $\mathrm{Fe}_{3} \mathrm{O}_{4}$-Loaded Activated Carbon Pre- pared from Waste Biomass," Chemical Engineering Journal, Vol. 160, No. 1, 2010, pp. 4-9. http://dx.doi.org/10.1016/j.cej.2010.03.003

[13] Z. Liu and F.-S. Zhang, "Nano-Zerovalent Iron Contained Porous Carbons Developed from Waste Biomass for the Adsorption and Dechlorination of PCBs," Bioresource Technology, Vol. 101, No. 7, 2010, pp. 2562-2564. http://dx.doi.org/10.1016/j.biortech.2009.11.074

[14] H. P. Yang, R. Yan, H. P. Chen, D. H. Lee and C. G. Zheng, "Characteristics of Hemicellulose, Cellulose and Lignin Pyrolysis," Fuel, Vol. 88, No. 12-13, 2007, pp. 1781-1788. http://dx.doi.org/10.1016/j.fuel.2006.12.013

[15] J. A. Conesa, A. Marcilla, J. A. Caballero and R. Font, "Comments on the Validity and Utility of the Different Methods for Kinetic Analysis of Thermogravimetric Data," Journal of Analytical and Applied Pyrolysis, Vol. 58-59, 2001, pp. 617-633. http://dx.doi.org/10.1016/S0165-2370(00)00130-3

[16] J. J. M. Órfão, F. J. A. Antunes and J. L. Figueiredo, "Pyrolysis Kinetics of Lignocellulosic Materials: Three Independent Reactions Model," Fuel, Vol. 78, No. 3, 1999, pp. 349-358. http://dx.doi.org/10.1016/S0016-2361(98)00156-2

[17] F. Gutiérrez, A. Rojas Bourillón, H. Dormond, M. Poore and W. Ching-Jones, "Características Nutricionales y Fermentativas de Mezclas de Desechos de Piña y Avícolas," Agronomía Costarricense, Vol. 27, No. 1, 2003, pp. 79-89.

[18] P. McKendry, "Energy Production from Biomass (Part 2): Conversion Technologies," Bioresource Technology, Vol. 83 , No. 1, 2002, pp. 47-54. http://dx.doi.org/10.1016/S0960-8524(01)00119-5

[19] F. He and D. Zhao, "Manipulating the Size and Dispersibility of Zerovalent Iron Nanoparticles by Use of Carboxymethyl Cellulose Stabilizers," Environmental Science and Technology, Vol. 41, No. 17, 2007, pp. 62166221. http://dx.doi.org/10.1021/es0705543

[20] X. Shen, L. Jiang, Z. Ji, J. Wu and H. Zhou, "Stable Aqueous Dispersions of Graphene Prepared with Hexamethylenetetramine as a Reductant," Journal of Colloid and Interface Science, Vol. 354, No. 2, 2011, pp. 493-497. http://dx.doi.org/10.1016/j.jcis.2010.11.037

[21] X. Zhang, S. Lin, X.-Q. Lu and Z.-L. Chen, "Removal of $\mathrm{Pb}$ (II) from Water Using Synthesized Kaolin Supported Nanoscale Zero-Valent Iron," Chemical Engineering Journal, Vol. 163, No. 3, 2010, pp. 243-248. http://dx.doi.org/10.1016/j.cej.2010.07.056

[22] L. B. Hoch, E. J. Mack, B. W. Hydutsky, J. M. Hershman, J. M. Skluzacek and T. E. Mallouk, "Carbothermal Synthesis of Carbon-Supported Nanoscale Zero-Valent Iron Particles for the Remediation of Hexavalent Chromium," Environmental Science and Technology, Vol. 42, No. 7, 2008, pp. 2600-2605. http://dx.doi.org/10.1021/es702589u

[23] A. Kabata-Pendias, "Trace Elements in Soils and Plants," Taylor and Francis Group, LLC., Boca Raton, 2011.

[24] P. T. Williams and A. R. Reed, "Pre-Formed Activated Carbon Matting Derived from the Pyrolysis of Biomass 
Natural Fibre Textile Waste," Journal of Analytical and Applied Pyrolysis, Vol. 70, No. 2, 2003, pp. 563-577.

http://dx.doi.org/10.1016/S0165-2370(03)00026-3

[25] H. Tamura, A. Tanaka, K. Mita and R. Furuichi, "Surface
Hydroxyl Site Densities on Metal Oxides as a Measure for the Ion-Exchange Capacity," Journal of Colloid and Interface Science, Vol. 209, No. 1, 1999, pp. 225-231. http://dx.doi.org/10.1006/jcis.1998.5877 